\title{
Post-Social politics, employability, and the security effects of higher education
}

\author{
Jon Frauley
}

Abstract: Trends within Western capitalist societies toward the individualizing of social problems, the responsibilizing of individuals for such problems, the treating of social problems as problems of control, ongoing attempts to shift the burden for safety and security from the state to the market, and changing conceptions of citizenship, have produced a context within which economic insecurity appears as a governable problem for higher education. Canada's most populous province, Ontario, experienced radical education reforms during the "common sense revolution" of the Progressive Conservative government from 1995 to 2003. The paper examines government documents, committee and task force reports, and legislative debates and hearings pertaining to these restructuring efforts and draws on the work of Michel Foucault and political sociology to explore the 'security effects' of higher education and the latter's conceptual relationship to employability. Higher education policy and restructuring, shaped as it is by human capital theory, takes employability to be an outcome of restructuring. However, as the paper shows, in an attempt to produce 'security effects', employability operated as a central and constitutive category of governance around which education policies as regulatory strategies were crafted. In the recent emergence of a 'next step' in the production of the security effects of education employability is displaced by innovation.

Key words: higher education policy, economic security, governance, regulation, public administration, capital, employability, innovation

\section{Post-Social Politics, Employability, and the Security Effects of Higher Education}

Education is perhaps the most important mechanism of social ordering in Western societies. It plays a key role in the process of societal reproduction. The "neoliberalization" of education within Western capitalist states entails restructuring systems of education; not toward making them better at pro- 
moting learning and intellectual curiosity but toward boosting economic productivity. ${ }^{1}$ In the 1980 s and 1990 s many states began reorganizing higher education to make it more efficient at producing distinctly employable graduates. Viewed through the concept of employability, students are reconceptualised as active, entrepreneurial, and (future) market dependent subjects who organize their daily practices around commercial norms. Thus the aim of restructuring around employability is to better prepare graduates for seemingly new economic realities in order to increase economic productivity and economic security. "One of the most significant developments", according to political sociologists Carroll and Beaton, "has been the identification of the campus as a site for creating or enhancing the profit-making capacity of individuals, business or the country itself" (Carroll \& Beaton, 2000, p.2, drawing on Noble).

Under the guise of improving access to higher education, Western governments promoted what I will call (drawing on Spitzer, 1987) the "security effect" of employability; that is, promoted employability as an outcome of the acquisition of educational capital to which a positive economic value had been attached. ${ }^{2}$ An unaddressed problem with this neoliberalization of higher education, however, rests with the human capital theory inspired assumption that employability is an outcome of restructuring. What we see, however, when looking at policy documents is that 'employability' is not an outcome of reform but a constitutive category of regulation around which the restructuring of education and subjectivity are shaped. "Employability", and more recently "innovation", are examples of what Davies and Guppy (1997) have called "global rationalizations" which have helped homogenize education policy across different regions of the globe. These are governmental rationalities that authorise particular understandings and sets of practices.

This paper explores employability as a regulatory concept and looks at its relationship to education's "security effects": the promotion of economic security through acquisition of educational capital. In exploring the relationship between employability and the security effects of education the paper draws on the work of Michel Foucault, Pierre Bourdieu, and political sociology. This paper examines education policy in Ontario, Canada to illustrate that in an attempt to produce security effects, employability was presented as the objective and outcome of restructuring, but operated as a

1 See Axelrod, 2002; Cote and Allahar, 2007; Guppy \& Davies, 1998; Gillies, 2011; Halliday, 1993; Jones, 2008; Kopecky, 2011; Larner and Herron, 2005; Marks, 1999; Perry, 2006; Peters, 2001; Rhoades \& Slaughter, 1997; Sears 2000, 2003; Slaughter \& Leslie, 1997; Tombs \& Whyte, 2003; Tudiver, 1999; Walters, 2003; White, 2001.

2 My understanding and use of the concept 'capital' is derived from the work of social anthropologist, Pierre Bourdieu (1967, 1979/1984, 1983/1986, 1984/1991b, 1987/1990). 
constitutive category of governance around which education policies as regulatory strategies were crafted. The focus on Ontario is to avoid the pitfall of over-generalization found in many theoretical works that are developed apart from specific engagement with an empirical referent. As Larner (2000, p. 12) suggests with reference to the influential Foucauldian inspired studies of governmentality, much of this literature "has not paid a great deal of attention to the politics surrounding specific programmes and policies...particularly the case vis-à-vis theorizations of neo-liberalism in that the emphasis has been on broad governmental themes rather than specific neo-liberal projects". The paper draws on news releases, background papers, discussion and consultation papers, committee and task force reports, legislative debates and legislative ad hoc committee hearings published between January 1995 and March 2003 by the former Progressive Conservative (PC) government of the Province of Ontario. It also looks at a recent consultation paper published by the current Liberal Party Government. As the position advanced is empirically grounded in a capitalist market society similar to that of the UK, Australia and New Zealand, it will resonate broadly.

In order to ground my argument and contextualize the theoretical discussion, the next section offers a discussion of the policy documents drawn on. Although a systematic and thorough discussion of all aspects of the documents is not possible due to space constraints, some of the key aspects of a selection of the more important documents will be highlighted here. This will provide illustration of the kinds of claims and statements that lead to the generation of the argument sketched out above and fleshed out in sections 2 and 3.

\section{The Ontario Case: Employability, Security, and Higher Education}

This section offers a delimited discussion of Ontario's education strategy of employability to empirically ground the next section's mainly theoretical discussion of employability and security effects, and the third section's discussion of innovation. The aim in this section is to show that employability is not an outcome but rather a constitutive category of governance. It should be noted that I am not simply speaking of credentialism but of a program of regulation that constitutes employability as the central object of governance in order to shape practical know-how and perceptions of political and economic life. This is in keeping with scholarship on the nature of governance and regulation in what has been termed the 'active society' or 'post-social state' (Ball, 2008; Dean, 1995; Garland 1996; 2001; Hunt, 
1993; 1994; 2002; Larner, 1997; 2000; O’Malley, 1996; Rose, 1996; Rose \& Miller, 1992; Walters, 1997).

The term 'regulation' refers to both a social process as well as a concept that is useful for conceiving of and for describing governance (Hunt, 1993). Regulation "involves the deployment of specific knowledges encapsulated in legal or quasilegal forms of interventions in specific social practices whose resultants have consequences for the distribution of benefits and detriments for the participants in the social practices subject to regulation" (Hunt, 1993, p. 314). Education is an example of one site of regulation and education policy the preeminent form of direct and indirect intervention into social, political, and economic life. To avoid a technicist notion of regulation as simply "rules", Hunt (1993, p. 314) argues that not only is regulation a process but that every instance of regulation is distinctly moral in nature: "all regulation involves the suppression, marginalization, or repudiation of alternative ways of being, while "encouraging" other realities". Further, regulation is constitutive or productive, following Foucault's arguments about the nature of power relations: it actively constitutes aspects of our subjective and social reality that we take to be unproblematic. Regulation has five emergent facets: (1) the object to be regulated, which is largely discursive in character (but not without some empirical referent); (2) the designated or identified regulatory agents who are charged with enforcing rules, following rules, and implementing strategies; (3) Regulatory knowledge that has been produced by agents about the objects (i.e., problems) that require regulation. This is linked to (4) the formation of strategies of regulation and policy objectives and, lastly (5) the rewards and sanctions that characterise the regulatory program. I will follow this scheme, especially in taking education policy to be a form of social and economic regulation.

The regulatory program of employability that is of concern here begins in 1996, shortly after the New Democratic Party (NDP) of Ontario was defeated by the Progressive Conservative (PC) party. A provincial background paper on changes to post-secondary funding in other Canadian provinces was released following the NDP's Royal Commission on Learning (Ontario, 1994; also see Ontario, 1995). The background paper stipulated that across Canada there had been increased emphasis on making post-secondary systems

more efficient, as well as more responsive to the needs of the students who are paying so much more to attend them. At the same time, skills training, and more broadly lifelong learning, has been identified as one way for individuals to respond to continuing high unemployment and increasing income inequality. (Drummond, 1996, p. 1) 
The emphasis on inefficiencies in systems of education set the tone for what would be a massive restructuring effort affecting all levels of education within Ontario (see Sattler, 2012). In this background report, education is identified as an inefficient but important site of individual empowerment for combating unemployment and welfare dependence. The notion that students are consumers and education a commodity as well as a market deeply permeates all subsequent documents on higher education released by the PC government. The educational field is conceptualised as one of commercial relations as 'education' is redefined to dovetail with economic policy in other sectors.

Following this initial report, a discussion paper called Future Goals for Ontario Colleges and Universities drew on OECD sensibilities to set out a solution to the problem of ineffectiveness and inefficiency. The paper emphasized, "Those in the labour force with either a postsecondary certificate or diploma or a university degree have consistently had a lower unemployment rate than those lacking these qualifications" (Ontario, 1996b, p.3). The perceived lack of efficiency in a system heralded as key to low unemployment resulted in a call by government for greater accountability by community colleges and universities. Two accountability mechanisms implemented were Key Performance Indicators (KPI) and the establishing of the Post-secondary Quality Assessment Board. ${ }^{3}$ New economic efficiencies were sought through streamlining programmes (including encouraging more cooperation between universities and community colleges) and implementing a new market driven model of education that included strategic investment in applied science and engineering. A subsequent move to increase the number of degree holders followed the recommendations of the Advisory Panel on Future Directions for Postsecondary Education (Ontario, 1996a). The emphasis here was on educational capital as a means of empowering individuals to combat economic insecurity and on the need for universities and community colleges to self-monitor and re-align to market forces. ${ }^{4}$ These early documents paved the way for the development of a governmental strategy that situated employability as a central concept.

3 Program proposed by out of province entities, non-chartered provincial entities, or pursuant to the amendment of existing degree granting chartered entities are subject to review (Ontario, 2002b; see also Ontario, 2000a,b,f,g). Programmes offered by all community colleges, private universities or new public universities such at UOIT are subject to review and oversight by the PSEQAB (see Ontario, 2001b,c).

4 This is known as 'reflexive government'. 'These practices', Dean (1995, p. 567) argues, 'also engage "clients" in their own government by demanding their complicity in these practices of self-shaping, self-cultivation and self-presentation.' 
Increasingly, an individual's employability depends on education, training, or retraining at the postsecondary level. To allow as many students as possible to achieve their educational goals, the postsecondary system should continually monitor its ability to offer the broad range of programs students require. It should also try to anticipate and respond promptly to new educational demands generated by emerging opportunities and fields of study, or by changes in employer and workforce requirements. (Ontario, 1996a, p. 6, emphasis added)

Employability is conceptualised in policy papers as a quality of the independent and active subject of neoliberalism and increasing access to higher education is imagined as one strategy for moving students directly to the labour market, thus lowering unemployment. The need to move quickly and directly to the labour market follows from radical state retrenchment.

Changing social policy priorities will also increase the demand for postsecondary education. The high priority placed by government on self-sufficiency and reduced dependence on social support programs will lead to an increased demand for the postsecondary and continuing education programs that can open up new routes to employment. (Ontario, 1996a, p. 8)

This strategy of employability attaches security effects to educational capital. This is because education's further alignment with the labour requirements of industry and increased responsiveness to market forces position employability, not employment, as an important factor in economic security.

Remarking on the University of Ontario Institute of Technology Act (Ontario, 2002a), the legislation to create Ontario's newest and first legally mandated market-driven university, the Minister of Training, Colleges, and Universities noted:

UOIT is part of our government's plan to ensure that we have the skilled people we need to attract investment to this province. This new approach to university education would give students greater choice and flexibility in programs tied directly to the changing needs of the marketplace. (Cunningham, 2001a, emphasis added)

The Minister further remarked on the production of "new recruits with the skills to enter the workforce", stipulating UOIT will

offer a wide range of opportunities to help students complete their degree. In short, the goal here is to provide one-stop shopping for students looking for a mix of academic and hands-on 
experience. UOIT would focus on degree programs, designed to meet current and future employment and economic development priorities, including applied health science, applied science, advanced manufacturing, policing and community safety, applied art, nuclear technology and safety, business and information technology and scientific and technological teacher education. (Cunningham, 2001a, emphasis added)

Clearly education is conceptualised as a market where clients (community colleges, universities, and departments) compete for an advantage in the labour market. Expansion of choice and opportunity included the creation of specialized degree programmes in applied science, increased funding to applied science, engineering and professional programmes, widening the field of higher education to lifelong learning, approval for private institutions to grant degrees as well as new applied degree programmes through community colleges. As the former Ontario Minister of Training, Colleges, and Universities put it, the then Progressive Conservative government was committed to making sure that "Ontarians have the appropriate kind and number of educational choices, including opportunities to earn a degree" (Ontario, 2000a, Minister's preface, emphasis added).

Despite claims that new education policies sought to increase accessibility to higher education, ${ }^{5}$ in practice this translated into a limiting of educational opportunities through strategically promoting the "appropriate kind and number of educational choices offered in areas where there is a demonstrated employer demand for degree-level applied education and training”(Ontario, 2000a, p. 7).

The need to practise fiscal restraint while expanding educational services means that funding must be based on clearly defined priorities. The criteria for allocating resources to postsecondary education should emphasize initiatives that can contribute to the economic development of the province and produce graduates who possess skills needed in the labour force. (Ontario, 1996b, p. 9; see Ontario, 1996a)

The UOIT's special mandate 'to provide career-oriented university programmes' (Ontario, 2002a, p. S3) and to cater to 'the market-driven needs of employers' (Ontario, 2002a, p. S4a) indicates that what was touted as increased opportunity to earn a degree concerned providing students with an (assumed or potential) economic value (see Ontario, 2001a, 2001i,

5 See 1998a,b; 1999a,c; 2000a,c,d,e,f,g,m; 2001d,f,g,h; 2002b,f. 
2002g). Particularly suggestive is the implicit claim that market aligned and driven applied fields of education are better value as they carry a higher rate of economic exchange than, for example, the social sciences or humanities (which, interestingly, are not offered at UOIT). ${ }^{6}$

Strategies for the expansion of choice and opportunity were geared toward promoting employability. Despite rhetoric holding employability to be a quality of the individual, educational capital to be empowering, and employment to be a natural outcome of aligning education and industry, within these policy papers employability operates as a central organising category of social regulation. Employability is not an outcome or quality of the individual but rather a constitutive category that is central to a strategy for regulating individuals and large populations and for moving subjects from one regulatory institution (education) to another (labour). Although the government was interested in credentialing students, what we see is how higher education was reorganized around a different category of subject the employable subject - one that is folded into a much broader programme of political governance.

A conflation of employability and employment is further illustrated in the example of Key Performance Indicators.

All new institutions will be subject to our key performance indicators that students are increasingly using to make informed decisions about their education futures, and they are taking these decisions very seriously. They want to know what percentage of students graduate and go on to get a job. (Ontario, 2000f, p. 5058-5059, emphasis added)

The KPI operate as a tool for future employables and potential unemployables to engage in the process of individualized risk management (to avoid negative risks or punishments in the labour market for selecting the 'wrong' degree programme); it also functions as a mechanism of fiscal accountability in that it regulates the allocation of operating grants to universities and community colleges (see Ontario, 2002b, c). This suggests a process of risk assessment both by the Board and by students, as well as the institutions themselves. This is to promote reflexive governance in that institutions

6 There are five objectives guiding higher education policy development - excellence, accessibility, range of programmes/institutions, accountability, responsiveness to evolving needs - four are expressly aimed at producing credentialed 'employable' workers. The 'appropriate' programmes of study were thought to 'contribute to the economic and social development of their communities' (Ontario, 1996b, p. 5, 6) through meeting 'current and future employment and economic development priorities' (Cunningham, 2001a). 
and students must self-monitor, continually adapt and re-align aspirations, practices, and priorities to larger programs of political governance. But Key Performance Indicators (KPI) (see Ontario, 2002b, c) lead one to mistake employability - considered a quality of graduates - for employment - the positioning of graduates in the labour market within a process of capital exchange. Here employability is conflated with employment yet operates as a constitutive category for policies designed to facilitate employment as outcome.

\section{Employability and Security}

Far from the suppositions of human capital theory (see Gillies, 2011; Green, 2007; Kopecky, 2011), employability is not a quality of person, an outcome of skilling or the acquisition of economic capital. It is a category of governance and has been employed to produce and regulate new categories of person. Following from the above and considering Hunt (1993), education as governance entails: (1) employability as a largely discursive object of regulation; (2) the emergence of students, teachers, professors, administrators, and state officials as regulatory agents employing a type of reflexive governance; (3) what comes to be understood as knowledge is produced through the use of Key Performance Indicators, student exit surveys, and internal audits; (4) the stated objective is that of increasing access to credentials as part of a strategy of employability; and (5) ability or the practical know-how (presumably) to convert educational capital into economic capital and the 'exchange rate' of the latter is the reward or punishment in the labour market for students' educational choices (i.e., their degree of risk calculation).

Literature on the emergence of what has been called a "post-social politics' (Rose, 1996; O’Malley, 1996) helps us frame how education, employability and security interlink. The market and smaller 'units' such as workplaces, schools, communities, and families have emerged as key sites for shaping and governing the moral imperatives and ethical commitments of 'active' subjects (Walters, 1997) or 'enterprising selves' (Rose, 1996). This dispersal of smaller units or sites of governance has fragmented 'the social' and in this context education has slowly been remodelled as a post-social site for empowering post-social selves to be independent of state supports and be self-sufficient. As markets are promoted as mechanisms for empowering subjects, families, and communities to obtain independence and to become self-sufficient (Cruickshank, 1994, 1996; Dean, 1999; O'Malley, 1997, 2000), education conceptualised as a market has become important for producing the kind of neoliberal subject that is expected to be easily and 'naturally' exposed to new forms of market dependency. 
New forms of market dependency are promoted in part through education's promotion of a particular form of politics of the self. This politics of the self and self-development works through empowering subjects to become self-sufficient, self-regulating and responsible: in short, active and enterprising (see Cruikshank, 1994, 1996; Dean, 1995, p. 567). This is the moral aspect of the employability strategy discussed by Hunt, above: "not only are firms to be entrepreneurial, enterprising and innovative, but so too are political subjects' (Larner, 2000, p. 13). People are encouraged 'to see themselves as individualized and active subjects responsible for enhancing their own well being... the citizen is re-specified as an active agent both able and obliged to exercise autonomous choices' (Larner, 2000, p. 13; see O'Malley, 1996, p. 28; Rose, 1996, p. 330). Sears (1999, p. 102) speaks of The lean person [who] is driven to maintain herself or himself at peak levels of fitness and generally organizes her or his life around lean principles, avoiding waste and dependence. The lean person is also a risk-taker, who adapts.' The lean person, or 'active citizen' (as discussed by Walters (1997, p. 224)) is held to be ethically and politically incomplete with 'the market the only true source for satisfaction of human desires and needs, just as participation in paid employment is the key to personal fulfilment, self-development and membership in society.' Post-social subjects are '[e]nterprising selves [who] work hard to obtain financial rewards [...] to pursue a commercially envisaged mode of self-development' (Heelas \& Morris, 1992, p. 4, emphasis added; see also O'Malley, 1993, p. 171, 2000, p. 17, 26).

Within this context of Western capitalist market societies, education's security effects are tied to how well it promotes and naturalizes the employable subject as a natural person that can be tightly integrated into labour markets and consumption. In this sense the strategy of employability is biopolitical in that it is concerned with producing, normalising, and regulating a population of employables (Foucault, 1978, 2003; Frauley, 2011). At the same time, to promote market integration and the category of employable subject successfully, education must also transmit what Bourdieu (1973, 1977) calls a "habitus" or "practical sense", one that is aligned with commercial norms and relations. Thus an employability strategy is also disciplinary along the lines discussed by Foucault in Discipline and Punish (1977) and The History of Sexuality (1978). Bourdieu's concept of habitus provides a very useful and quite underutilised way of thinking about discipline.

The production and distribution of educational capital instils what both Foucault (1988a, p. 18) and Bourdieu (1973, p. 67) refer to as a "matrix" of practical reason. It is this matrix of practical reason that is key to strategies of employability, not simply the acquisition of skills or information. Employ- 
ability concerns the production of a practical sense that emphasizes market relations and commercial norms:

"subjects" are active and knowing agents endowed with a practical sense, that is, an acquired system of preferences, of principles of vision and division (what is usually called taste), and also a system of durable cognitive structures (which are essentially the product of the internalisation of objective structures) and of schemes of action which orient the perception of the situation and the appropriate response. (Bourdieu, 1994/1998, p. 25)

This matrix is a "technology" as, according to Foucault (1988, p. 18), it concerns techniques that are used by human beings to understand and work on their capacities. These technologies imply "certain modes of training and modification of individuals, not only in the obvious sense of acquiring skills but also in the sense of acquiring certain attitudes" (Foucault, 1988, p. 18). Bourdieu discusses the nature and process of acquiring these durable "attitudes" (habitus). Different fields, Bourdieu argues, will produce different

classes of habitus ... by instilling different definitions of what is impossible, possible, probable and certain, the conditions of existence cause one group to experience as natural or reasonable the same practices or aspirations which the other group finds unthinkable or scandalous, and vice versa. (Bourdieu, 1973, p. 66; also Bourdieu, 1977, p. 78)

Employability designates a class of habitus, but it is not a subjective quality of social subjects. Rather it refers to a positioning within some structured field (Bourdieu, 1994/1998, p. 32). On this view, taking applied science in university does not make one more employable than a philosophy major. It is the structure of the labour market which enables or impugns the rate of exchange between certain types of educational capital and economic capital. This is significant for the security effects of education. Educational capital which has a relatively anaemic exchange rate will still have a security effect in that it is tied to employability, whereas it may not be tied with any significance to employment. Security effects are tied to potential economic capital, not employment. That is, security effects rest on employability (i.e., potential economic capital) - not on employment (i.e., actualised potential). Employability is a concept and category of regulation and employment is a material condition and structural position within a labour market.

Further, security effects are not ideational - what we believe - but concern the structure of social fields (and the habitus produced). Labour and 
education are examples of these fields. Foucault's work on security and governmentality, for instance, concerned the governance of such fields, especially the regulating of the emergence of possible forms of action and various classes of habitus. As it is the structure or configuration of such fields that enable or impugn outcomes, governing has very much to do with setting in place conditions for the realisation of some potentialities but not others (see Frauley, 2007). It concerns the organisation of the educational field as well as the field of work (in which this potential might be actualised). Educational capital is imbued through schooling but will only be realised as economic capital if the conditions within the labour market at right for capital exchange. Thus, making subjects employable is a governmental strategy about the potential imbued through disciplinary-regulatory processes within the educational field; employment is the realisation of this through disciplinary-regulatory processes within the field of work. The distinction between employability as potential and employment as actualisation of this potential is something that human capital theory, or at least human capital influenced education policy, seems to miss. Likewise, the official emphasis on individual responsibility and empowerment draws attention away from the organisational aspect of fields and the latter's role in enabling and constraining agency (particularly through the formation of habitus).

Education as a governmental project requires not only individual responsiveness but also institutional responsiveness to changes in the material and conceptual organisation of markets and the broader political economy (i.e., "reflexive government" (see Dean, 1999)). Policies organised around the category of employability which transmit a neoliberal habitus (i.e., capacity for reflexive (self) government and practical know-how) attempt to naturalise particular ways of being responsive. The "consumption" of educational capital through an education market is one example. This is clearly illustrated in the new market -driven model of higher education introduced by the former Progressive Conservative government of Ontario. The market driven model claims institutional responsiveness as well as production of the appropriate individual responsiveness via the habitus instilled. In this model educational capital is very much positioned as a commodity that has security effects.

As security is 'intimately related' to perceptions of insecurity (Spitzer, 1987, p. 46), and as labour markets today are characterized by precariousness rather than security, anything which is thought to enhance employability will produce what Spitzer terms "security effects". This is not simply about the commodificiation of education but how education comes to be endowed with economic value and have economic security effects whether or not graduates find employment. 
the boundaries around security services and products appear to be clear. The security commodity is something that is produced and consumed to make people feel safe, free from doubt, care, anxiety or apprehension. Yet upon closer examination a problem appears: since efforts to achieve safety, freedom from danger, assurance and confidence are essential features of everyday life under capitalist ... arrangements, it is necessary to distinguish between those aspects of the 'security market' which have emerged to address directly the safety of persons and property, and those whose connection to security is less tangible and direct. ... The attractiveness and market value of a broad range of commodities is enhanced precisely because they promise a greater degree of safety and freedom from anxiety than their alternatives. Because safety (like love, happiness, prosperity, and fulfilment) is a social need which can be activated in a wide range of decisions to consume, virtually all commodities can be invested with the 'aura' of security - that is, presented, promoted, and ultimately consumed because of their ostensible ability to free the consumer from worry, trouble, and harm. (Spitzer, 1987, p. 44-45, emphasis added)

An important feature of security commodities is that they promise potential freedom from things such as fear or anxiety; they promise potential independence from insecurity. In the case of education, policies are oriented toward the presentation, promotion and promise of a type of freedom from unemployment. It is potential that requires realisation. The documents examined present employability as the outcome of higher education and educational capital as a commodity to "free the consumer from worry, trouble, and harm". Employability, as a stated aim of education policy, is about the successful integration of students into commercial relations labour markets as well as goods and services. The production of security effects is a chief aim that follows from the concern with employability and educational capital as a security commodity. Educational capital is valuable because it has been assigned an economic value that responsible and enterprising citizens should be able to recognize, acquire, and later exchange.

\section{From Employability to Innovation}

Recently we have witnessed a shift from employability to "innovation". Innovation serves as a new central organising category that enables picturing and understanding education in a particular way (see Ontario, 2012). 
Economic productivity is no longer to be the result of only employable subjects gaining positions within the labour market but rather innovation in program delivery (Ontario, 2012, p. 7). It is "increased innovation" that is to "drive" and "improve" productivity (Ontario, 2012, p. 7-8). Innovations are defined as "new ideas, systems, and processes that create new learning and teaching modalities, improve learning outcomes, enhance the student experience, and create long-term savings through improved productivity" (Ontario, 2012, p. 8-9). One such system innovation is the professionalization of casual academic labour with the relatively new development of the "teaching track" or "teaching stream appointment".

Innovation and employability inform labour market policy disguised as education policy. From the supply side, they concern the shaping of not only the habitus of employable subjects but those already employed in the academic labour market. Here we have witnessed the creation of a new category of employment or new class of professor. The current "academic underclass" (Hira \& Cohen, 2011, p. 3) and newly minted PhDs form the basis of this new population of renewable full-time contract positions and/or tenurable teaching-only posts. According to Gravestock and Gregor Greenleaf (2008, p. 2), "Approximately one-quarter of institutions surveyed have a dedicated rank or set of ranks for those faculty whose primary responsibility is teaching (or teaching and service)". This is in part because, according to Clark, Trick and Van Loon (2011) who have extensively surveyed higher education systems and reform across North America and Europe, the model of the research university offers an unsustainable model of undergraduate education (see Clark, Moran, Skolnik, Trick, 2009). Innovation comes in the form of a 'differentiated system' (Clark, Trick, Van Loon, 2011) that includes creating teaching only universities or teaching track professorships within research intensive universities. This differentiated system appears necessary because, as Clark, Trick and Van Loon argue (drawing in several studies), one does not need to be an effective researcher to be an effective teacher and to not differentiate is to remain unsustainable. ${ }^{7}$

Employability strategies are likened to strategies of efficiency but, as a recent discussion paper published by the current Liberal Government of Ontario makes clear, an "innovation-focused approach [to productivity] is in direct contrast to an efficiency-focused approach" (Ontario, 2012, p. 9). No longer is employability a stated central aim but it does remain an important regulatory category. The stated aim now is system innovation in teaching and research delivery. Increased use of information technology as well

7 See also Gamson (1997) and Tirelli (1997) on differentiation in the academic labour market. 
as teaching-track appointments signals innovation in higher education and this is thought to drive economic productivity in other sectors. The production of new knowledge therefore is problematised: dissemination of existing knowledge in a more innovative way is held to be the answer.

Whereas productivity was earlier thought to be driven by employability, what is emerging now is the idea that innovation is a key driver. Although the 2012 consultation paper quoted above suggests strategies of employability and those of innovation are contrasting strategies of governance, both employability and innovation are regulatory categories that help to constitute security effects. These may be thought complementary in that greater employability (misperceived as an outcome) might be realised if there is system innovation and greater concentration on training undergraduates. Taking both strategies together could give us the following view of how education as social regulation is evolving: Access to education requires increased innovation in course delivery and undergraduate training, which boosts employability (as outcome) and ultimately will improve productivity (and market dependence). Security effects will be generated in that greater numbers will be subjected to market discipline in some or other form: either through consumption of lifelong learning or employment.

\section{Concluding Remarks}

This paper argues from an "education as governance" position and although it concerns education policy and the role of employability in the governance of economic security in the Province of Ontario, the analysis is germane to theoretical and empirical enquiry in other capitalist market societies. The paper offers a sketch of the security effects desired and promoted through higher education and its restructuring in Ontario. Under the guise of improving access to higher education, governments promoted employability as a "security effect", as something derived from select forms of educational capital. However, as this paper demonstrates, employability is a central constitutive concept in the formulation of educational and social governance, not a material outcome of acquiring educational capital. Strikingly, education policies fail to distinguish between employability as potential and employment as the realization of this potential. The structure of labour markets as a key factor in the realisation of economic capital is neglected as issues of economic security are held to be individual issues and education ideologically conceptualised as a site of individual empowerment.

Educational systems recently have shifted slightly away from the charge to produce employable subjects toward becoming more innovative in "education delivery" (Ontario, 2012, p. 10). The most recent documents position 
innovation as a condition of employability because innovation is now considered a key factor in boosting capital acquisition. Innovative (and reflexive) systems are thought to provide better value for money (Clark, Trick \& Van Loon, 2011) and so therefore thought to lead to increased productivity. Employability and innovation are considered to be key factors for employment because greater numbers of students can be empowered in a timely manner, which means increases in populations of market dependent citizens. However, employability and innovation are not simply objectives but constitutive regulatory categories that aid in conceputalizing the educational field and facilitate its reorganisation, in turn shaping the practices and the habitus of actors. Both strategies organised around employability and innovation concern the production of security effects and regulation of the emergence of economic insecurities at both an institutional and individual level.

\section{References}

Axelrod, P. (2002). Values in conflict: The university, the marketplace, and the trials of liberal education. Montreal: McGill-Queen's UP.

Ball, S. (2008). New Philanthropy, new networks and new governance in education. Political Studies, 56(4), 747-765.

Bourdieu, P. (1967). Systems of education and systems of thought. In Social Science Journal, 19(3), 338-358.

Bourdieu, P. (1973). The three forms of theoretical knowledge. In Social Science Information, 12(1), 53-80.

Bourdieu, P. (1977). Outline of a theory of practice. New York: Cambridge UP.

Bourdieu, P. (1979/1984). Distinction: A social critique of the judgement of taste. Cambridge, MA: Harvard UP.

Bourdieu, P. (1983/1986). The forms of capital. In J. G. Richardson (Ed.), Handbook of theory and research for the sociology of education. (pp. 241-258). New York: Greenwood Press.

Bourdieu, P. (1984/1991b). On symbolic power. In Language and symbolic power. (pp.163-170). Cambridge, MA: Polity Press.

Bourdieu, P. (1987/1990). Social space and symbolic power. (pp.123-139), In In Other Words. Cambridge: Polity Press.

Bourdieu, P. (1994/1998). Practical reason: On the theory of action. Cambridge, MA: Polity Press.

Carroll, W., \& Beaton, J. (2000). Globalization, neo-liberalism, and the changing face of corporate hegemony in higher education. In Studies in Political Economy, 62, summer, 71-98.

Clark, I., Moran, G., Skolnik, M., \& Trick, D. (2009). Academic transformation: The forces reshaping higher education in Ontario. Montreal: McGill-Queen's UP. 
Clark, I., Trick, D., \& Van Loon, R. (2011). Ontario reticence in higher education: Time to contemplate major system reform. The Blue and White, Retrieved February 9, 2012, from http://the blueandwhite.ca/article/2011/02/09/00/00/04/ontarioreticence-in-higher-education.html

Cote, J., \& Allahar, A. (2007). Ivory tower blues: A university system in crisis. Toronto: University of Toronto Press.

Cotterrell, R. (1995). Law's community: Legal theory in sociological perspective. New York: Oxford University Press.

Cruikshank, B. (1994). The will to empower: Technologies of citizenship and the war on poverty. In Socialist Review, 23(4), 29-55.

Cruikshank, B. (1996). Revolutions within: Self-government and self-esteem. In A. Barry, T. Osborne, \& N. Rose (Eds.), Foucault and political reason: Liberalism, neoliberalism and rationalities of government. (pp. 231-235). Chicago: University of Chicago Press.

Cunningham, D. (2001a). Introduction to the legislature of the Act to establish the University of Ontario Institute of technology, 2001. Toronto: Legislative Assembly of Ontario. Retrieved November 27, 2012, from http://www.edu.gov.on.ca/eng/document/nr/01.11/st1127.html

Cunningham, D. (2001b). Government's plan for the double cohort: Statement to the legislature. Toronto: Legislative Assembly of Ontario. Retrieved May 15, 2012, from http://www.edu.gov.on.ca/eng/document/nr/01.05/st0515.html

Cunningham, D. (2002). First reading -- Post-secondary education student opportunity act, 2002. Toronto: Legislative Assembly of Ontario. Retrieved May 30, 2012, from http://www.edu.gov.on.ca/eng/document/nr/02.05/st0530.html

Davies, S., \& Guppy, N. (1997). Globalization and educational reforms in AngloAmerican democracies. In Comparative Education Review, 41(4), 435-59.

Dean, M. (1995). Governing the unemployed self in an active society. In Economy and Society, 24(4), 559-83.

Dean, M. (1999). Governmentality: Power and rule in modern society. Thousand Oaks, CA: Sage.

Drummond, A. (1996). Backgrounder: Post-secondary education reforms in other provinces. Toronto: Legislative Research Service (Ontario Legislative Library).

Foucault, M. (1970/1972). The discourse on language. In The archaeology of knowledge. New York: Pantheon, 215-37.

Foucault, M. (1977). Discipline and punish: The Birth of the prison. New York: Vintage.

Foucault, M. (1978). The History of sexuality, Vol. 1. New York: Vintage.

Foucault, M. (2003). Lecture 11: 17 March 1976 In 'Society must be defended': Lectures at the College de France, 1975-76. New York: Picador.

Foucault, M. (1988). Technologies of the self. In Martin, L., Gutman, H., \& Hutton, P. (Eds.), Technologies of the self: A seminar with Michel Foucault. (pp. 16-49). Amherst: University of Massachusetts Press. 
Frauley, J. (2007). Toward an archaeological-realist Foucauldian analytics of government. In British Journal of Criminology, 47 (4), 617-633.

Frauley, J. (2011). Biopolitics and the governance of genetic capital in GATTACA. In Criminology, Deviance and the Silver Screen: The Fictional Reality and the Criminological Imagination. New York: Palgrave, 195-216.

Gamson, Z. (1997). The Stratification of the academy. In Social Text, 15(2), 67-73.

Garland, D. (1996). The limits of the sovereign state: Strategies of crime control in contemporary society. In British Journal of Criminology, 36(4), 445-71.

Garland, D. (2001). The culture of control: Crime and social order in contemporary society. Chicago: University of Chicago Press.

Gillies, D. (2011). State education as high-yield investment: Human capital theory in European policy discourse. In Journal of Pedagogy, 2(2), 224-245.

Gravestock, P. And Greenleaf, E. (2008). Overview of Tenure and Promotion Policies Across Canada. Retrieved July, 15, 2012, from http://www.mtroyal.ca/wcm/ groups/public/documents/pdf/aptc_canada_tenurepolicies.pdf

Guppy, N., \& Davies, S. (1998). Education in Canada: Recent trends and future challenges. Ottawa: Minister of Industry (Statistics Canada).

Halliday, J. (1993). Maoist Britain? The ideological function of vocationalising the higher education curriculum. Curriculum Studies, 1(3), 365-82.

Heelas, P., \& Morris, P. (1992). Enterprise culture: Its values and value. In P. Heelas, $\&$ P. Morris (Eds.), The Values of the enterprise culture: The Moral debate. (pp. 1-26) New York: Routledge.

Hira, A., \& Cohen, D. (2011). Professionalising academics: A Review of issues in higher education assessment systems. Retrieved July, 15, 2012, from http://www. sfu.ca/ ahira/Professionalizing\%20Academics\%20apr\%201\%2011.pdf

Hunt, A. (1993). Explorations in law and society: Towards a constitutive theory of law. New York: Routledge.

Hunt, A. (2002). Legal governance and social relations: Empowering agents and the limits of law. In M. McNeil, N. Sargent, \& P. Swan (Eds.), Law, regulation, and governance. (pp. 54-77). Toronto: Oxford UP.

Hunt, A. \& Wickham, G. (1994). Foucault and law: Towards a sociology of law as governance. Boulder: Pluto Press.

Jones, G. (2008). The University and society. In Curriculum Inquiry, 38(4), 417-432.

Kopecky, M. (2011). Foucault, governmentality, neoliberalism and adult education: Perspective on the normalization of social risks. In Journal of Pedagogy, 2(2), 246-262.

Larner, W. (2000). Neo-liberalism: Policy, ideology, governmentality. In Studies in Political Economy, 63, 5-25.

Larner, W., \& Heron, R. (2005). Neo-liberalizing spaces and subjectivities: Reinventing New Zealand universities. In Organization, 12(6), 843-62.

Loader, I. (1999). Consumer culture and the commodification of policing and security. In Sociology, 33(2), 373-92. 
Marks, A. (1999). Really useful knowledge: The 'new vocationalism' in higher education and its consequences for mature students. In British Journal of Educational Studies, 47(2), 157-69.

O'Malley, P. (1993). Containing our excitement: Commodity culture and the crisis of discipline. In Studies in Law, Politics, and Society, 13, 159-186.

O’Malley, P. (1996). Post-social criminologies: Some implications of current political trends for criminological theory and practice. In Current Issues in Criminal Justice 8, 1-13.

O’Malley, P. (1997). Risk and responsibility. In Barry, Osborne, and Rose, (Eds.), Foucault and political reason: liberalism, neo-liberalism and rationalities of government. (pp. 189-207). Chicago: University of Chicago Press.

O'Malley, P. (2000). Risk societies and the government of crime. In Brown, M., \& Pratt, J. (Eds.), Dangerous offenders: Punishment and social order. (pp- 17-34). New York: Routledge.

Ontario. (1994). For the love of learning: Final report. Toronto: Royal Commission on Learning. Ministry of Education and Training.

Ontario. (1995). News release: Royal commission on learning provides a blueprint for changing Ontario schools. Toronto: Ministry of Education and Training. Retrieved January 26, 2012, from http://www.edu.gov.on.ca/eng/general/abcs/rcom/news. html

Ontario. (1996a). Excellence, accessibility, responsibility. Toronto: Advisory panel on future directions for postsecondary education, Ministry of Education and Training.

Ontario. (1996b). Future goals for Ontario colleges and universities: Discussion paper. Toronto: Ministry of Education and Training.

Ontario. (1998a). Backgrounder: Access to opportunities program. Toronto: Ministry of Education and Training. Retrieved May 29, 2012, from http://www.edu.gov. on.ca/eng/document/nr/98.05/tech-bg.html

Ontario. (1998b). News release: Thousands of new student spaces to be created in high-demand technical programs, Johnson says. Toronto: Ministry of Education and Training. Retrieved May 29, 2012, from http://www.edu.gov.on.ca/eng/document/ nr/98.05/tech.html

Ontario. (1999a). Backgrounder: Access to opportunities program. Toronto: Ministry of Training, Colleges and Universities. Retrieved July, 20, 2012, from http://www. edu.gov.on.ca/eng/document/nr/99.07/atopbg.html

Ontario. (1999c). News release: Expectations surpassed as college and universities create new student spaces in high-tech programs, Cunningham says. Toronto: Ministry of Training, Colleges and Universities. Retrieved July 14, 2012, from http:/ / www. edu.gov.on.ca/eng/document/nr/99.07/atop.html

Ontario. (2000a). Increasing degree opportunities for Ontarians. Toronto: Ministry of Training, Colleges and Universities.

Ontario. (2000b). Backgrounder: Highlights of operating grants and tuition announcement. Toronto: Ministry of Training, Colleges and Universities. Retrieved March, 20, 2012, from http://www.edu.gov.on.ca/eng/document/nr/00.03/spacebg.html 
Ontario. (2000c). News release: Government invests in more student spaces, quality programs. Toronto: Ministry of Training, Colleges, and Universities. Retrieved March 14, 2012, from http://www.edu.gov.on.ca/eng/document/nr/00.03/space.html

Ontario. (2000d). News release: Government promotes excellence and choice in Ontario's postsecondary education system. Toronto: Ministry of Training, Colleges and Universities. Retrieved April 28, 2010, from http://www.edu.gov.on.ca/eng/document/nr/00.04/deg.html

Ontario. (2000e). Backgrounder: Improving the quality and accessibility of postsecondary education and training. Toronto: Ministry of Training, Colleges and Universities. Retrieved September 12, 2012, from http://www.edu.gov.on.ca/eng/document/nr/00.09/improve.html

Ontario. (2000f). Backgrounder: Ontario's comprehensive plan for postsecondary education. Toronto: Ministry of Training, Colleges and Universities. Retrieved, October 19, 2012, from http://www.edu.gov.on.ca/eng/document/nr/00.10/excelbe.html

Ontario. (2000g). News release: Ontario expands choice and excellence for students in colleges and universities. Toronto: Ministry of Training, Colleges and Universities. Retrieved October 19, 2012, from http://www.edu.gov.on.ca/eng/document/ $\mathrm{nr} / 00.10 /$ excelle.html

Ontario. (2000h). Hansard, No. 95B. Toronto: Legislative Assembly of Ontario.

Ontario. (2000i). Hansard, G-34, Report of proceedings on ministry of training, colleges and universities statute law amendment act, 2000 (Bill 132). Toronto: Standing Committee on General Government, Legislative Assembly of Ontario.

Ontario. (2000j). Hansard, G-35, Report of proceedings on ministry of training, colleges and universities statute law amendment act, 2000 (Bill 132). Toronto: Standing Committee on General Government, Legislative Assembly of Ontario.

Ontario. (2000k). Hansard, G-37, Report of proceedings on ministry of training, colleges and universities statute law amendment act, 2000 (Bill 132). Toronto: Standing Committee on General Government, Legislative Assembly of Ontario.

Ontario. (20011). Hansard, G-38, Report of proceedings on ministry of training, colleges and universities statute law amendment act, 2000 (Bill 132). Toronto: Standing Committee on General Government, Legislative Assembly of Ontario.

Ontario. (2000m). News release: News legislation will offer more choice to postsecondary students. Toronto: Ministry of Training, Colleges and Universities. Retrieved December 20, 2012, from http://www.edu.gov.on.ca/eng/document/nr/00.12/ choice.html

Ontario. (2001). Portals and pathways: A review of postsecondary education in Ontario. Toronto: Investing in Students Task Force, Ministry of Training, Colleges and Universities.

Ontario. (2001a). News release: Canada's newest university to meet the demands for market-driven degree programs-province to invest $\$ 60$ million in Ontario Institute of Technology. Toronto: Ministry of Finance. Retrieved October 4, 2012, from http:// www.gov.on.ca/FIN.english/media/2001/nre-oit.htm 
Ontario. (2001b). Backgrounder: Postsecondary education quality assessment board (PEQAB). Toronto: Ministry of Training, Colleges and Universities. Retrieved April 17, 2012, from http://www.edu.gov.on.ca/eng/document/nr/01.04/bg0417.html

Ontario. (2001c). News release: Advisory board to ensure quality in new postsecondary programs. Toronto: Ministry of Training, Colleges and Universities. Retrieved April 17, 2012, from http://www.edu.gov.on.ca/eng/document/nr/01.04/nr0417. html

Ontario. (2001d). Backgrounder: Preparing for the double cohort, Toronto: Ministry of Training, Colleges and Universities. Retrieved May 15, 2012, from http://www.edu. gov.on.ca/eng/document/nr/01.05/bg0515.html

Ontario. (2001e). Hansard, No. 21B. Toronto: Legislative Assembly of Ontario.

Ontario. (2001f). Backgrounder: A place for every qualified student. Toronto: Ministry of Training, Colleges and Universities. Retrieved June 19, 2012, from

http://www.edu.gov.on.ca/eng/ document/nr/01.06/bg0619.html

Ontario. (2001g). News release: Ontario funding for colleges and universities increased to $\$ 2.5$ billion. Toronto: Ministry of Training, Colleges and Universities. Retrieved June 19, 2012, from http://www.edu.gov.on.ca/eng/document/nr/01.06/nr0619. html

Ontario. (2001h). News Release: Students to benefit from more choices in degrees. Toronto: Ministry of Training, Colleges and Universities. Retrieved October 1, 2012, from http://www.edu.gov.on.ca/eng/document/nr/01.10/nr1001.html

Ontario. (2001i). News release: Students and Durham region benefit from new university. Toronto: Ministry of Training, Colleges and Universities. Retrieved November 27, 2012, from http://www.edu.gov.on.ca/eng/document/nr/01.11/nr1127a.html

Ontario. (2002a). University of Ontario Institute of Technology Act, 2002, S.O. 2002, c.8 s.0, as am. S.O. 2002, c.24, sched. B, s.48. Toronto: Legislative Assembly of Ontario. Retrieved November 27, 2012, from http:/ /www.e-laws.gov.on.ca/DBLaws / Statutes/English/02u08o_e.htm

Ontario. (2002b). Post-secondary education choice and excellence act, 2000, S.O. 2000, C.36, as am. S.O. 2002, c.8, Sched. F, s.11. Toronto: Legislative Assembly of Ontario. Retrieved November 27, 2012, from http:/ /www.e-laws.gov.on.ca/DBLaws / Statutes/English/00p36_e.htm

Ontario. (2002c). News release: Universities receive $\$ 23.2$ million funding based on performance. Toronto: Ministry of Training, Colleges and Universities. Retrieved February 27, 2012, from http://www.edu.gov.on.ca/eng/document/nr//02.02/ nr0208.html

Ontario (2002d). Backgrounder: New applied degree programs at Ontario colleges. Toronto: Ministry of Training, Colleges and Universities. Retrieved March 27, 2012 from http:/ / www.edu.gov.on.ca/eng/document/nr/02.03/bg0327.html

Ontario. (2002f). News release: Students have more choice as Ontario colleges begin offering 12 applied degree programs. Toronto: Ministry of Training, Colleges and Universities. Retrieved March 27, 2012, from http://www.edu.gov.on.ca/eng/document/nr/02.03/nr0327.html 
Ontario. (2002g). News release: Eves government launches new university, expands college in Durham. Toronto: Ministry of Training, Colleges and Universities. Retrieved 28 November, 2012, from http://www.edu.gov.on.ca/eng/document/nr/02.11/ nr1 128.html

Ontario. (2012). Strengthening Ontario's centres of creativity, innovation and knowledge. Toronto: Ministry of Training, Colleges, and Universities.

Pearce, F. \& Valverde, M. (Eds.). (1996). Conflict, contradiction and governance (special issue of Economy and Society), 25(3).

Peters, M. (2001). Education, enterprise culture and the entrepreneurial self: A Foucauldian perspective. In Journal of Educational Enquiry, 2(2), 58-70.

Perry, B. (Ed.). (2006). Universities in the knowledge economy: Places of expectation/ spaces for reflection (special issue of Social Epistemology), 20(3/4).

Rhoades, G., \& Slaughter, S. (1997). Academic capitalism, managed professionals, and supply-side higher education. In Social Text, 15(2), 9-38.

Rose, N. (1992). Governing the enterprising self. In Heelas, P., \& Morris, P. (Eds.), The values of the enterprise culture: The moral debate. (pp. 141-164). New York: Routledge.

Rose, N. (1999). Powers of freedom: Reframing political thought. Cambridge: Cambridge UP.

Sattler, P. (2012). Education governance reform in Ontario: Neoliberalism in context. In Canadian Journal of Educational Administration and Policy, 128, January, 1-28.

Sears, A. (1999). The 'lean' state and capitalist restructuring: towards a theoretical account. In Studies in Political Economy, 59, 91-114.

Sears, A. (2000). Education for a lean world. In M. Burke, C. Mooers, \& J. Shields (Eds.), Restructuring and resistance: Canadian public policy in an age of global capitalism. (pp. 146-158) Halifax: Fernwood.

Sears, A. (2003). Retooling the mind factory: Education in a lean state. Aurora ON: Garamond.

Slaughter, S., \& Leslie, L. (1997). Academic capitalism: Politics, policies, and the entrepreneurial university. Baltimore: Johns Hopkins UP.

Spitzer, S. (1987). Security and control in capitalist societies: the fetishism of security and the secret thereof. In J. Lowman, R. Menzies, \& T. Palys (Eds.), Transcarceration: Essays in the sociology of social control. (pp. 43-58). Brookfield VT: Gower.

Tirelli, V. (1997). Adjuncts and more adjuncts: Labor segmentation and the transformation of higher education. In Social Text, 15(2), 75-91.

Tombs, S., \& Whyte, D. (2003). Scrutinizing the powerful: Crime, contemporary political Economy, and critical social research. In S. Tombs, \& D. Whyte (Eds.), Unmasking the crimes of the powerful: scrutinizing states and corporation. (pp. 3-45). New York: Peter Lang.

Tudiver, N. (1999). Universities for sale. Toronto: James Lorimer \& Co.

Walters, R. (2003). New modes of governance and the commodification of criminological knowledge. Social \& Legal Studies, 12(1), 5-26. 
Walters, W. (1997). The 'active society': New designs for social policy. In Policy and Politics, 25(3), 221-34.

White, R. (2001). Criminology for sale: Institutional change and the intellectual field. In Current Issues in Criminal Justice, 13(1), 123-42.

\section{Author:}

Jon Frauley, Ph.D., Assistant Professor

University of Ottawa

Faculty of Social Science

Department of Criminology

120 University St.

Ottawa

ON K1N 6N5

Canada

email: jfrauley@uottawa.ca 